\title{
The Effect Of Learning Models and Cognitive Style on Mathematics Learning Outcomes Of Grade 5 Students
}

\author{
Riama Lusia Sirait \\ Educational Technology, Postgraduate Program \\ Universitas Negeri Medan \\ Medan, Indonesia \\ Corresponding email: riamalusia_sirait@yahoo.com \\ Abdul Muin Sibuea \\ Educational Technology, Postgraduate Program \\ Universitas Negeri Medan \\ Medan, Indonesia \\ Abdul Murad \\ Educational Technology, Postgraduate Program \\ Universitas Negeri Medan \\ Medan, Indonesia
}

\begin{abstract}
This study aims to find out the effect of problem posing learning model and cognitive style on mathematics learning outcomes. This study used a quasi-experimental research designs. The population consisted of 68 grade 5 students in Deliserdang. The sample consisted of 46 students that were divided into two groups (experimental group and control group). The instruments used were mathematics test and Children's Embedded Figure Test (CEFT). The data which analyzed in this research was the score of mathematics learning outcomes from cognitive domain. The data was analyzed using Two-Way ANOVA technique (analysis of variance). The result of the research are as follows. (1) There is a difference between students' mathematics learning outcomes which is taught using problem posing learning model with direct learning model, (2) There is a difference between student's mathematics learning outcomes who have field independent (FI) with field dependent (FD) cognitive style, (3) There is no significant interaction between the use of learning model and the cognitive style on learning outcomes.

Keywords- problem posing, direct learning, cognitive style, mathematics' learning outcomes.
\end{abstract}

\section{INTRODUCTION}

Recognizing the diversity among students and understanding how different students learn are the most important challenges we will face as a teacher [1]. It takes no special knowledge of research to recognize that we all have characteristic 'style' for collecting and organizing information into useful knowledge. Psychologist label these mental characteristic cognitive style [2]. Cognitive style describes consistencies in using cognitive process. It does not describe the content or cognitive level of individual's performances. Cognitive style include stable attitudes, preferences, or habitual strategies that distinguish the individual style of perceiving, remembering, thinking, and solving problem. Cognitive style reflects a person's way of responding and performing in diverse situations[3]. Cognitive style have been identified to influence students' academic achievement. Students with different types of cognitive style may need different instructional strategies to suit their information processing needs and learners preferences [4].

Field dependence independence (FDI) characterizes one dimension of perceiving, remembering, and thinking as an individual apprehends, stores, transforms, and processes information[3]. Field dependence and independence refers to the degree "to which the organization of the prevailing field dominates perception of any of its part" (Witkin, 1971). It is an expression of an individual's cognitive psychological structure to separate contextual information (Witkin \& Goodenough, 1981). It is also describe " the degree to which a learner's perception of comprehension of information is affected by surrounding perceptual or contextual field' (Jonassen \& Grabowski, 1993)[4].

The construct of field dependence-independence as one of the cognitive style dimensions which has generated the most research for cognitive restructuring and social behavior. FD and FI individuals have different behavioral characteristics that identify their cognitive styles and categorize them as a more FD (global or undifferentiated) or a more FI (analytic or differentiated) person. FD and FI cognitive styles represent distinctly different methods of processing 
information. F1 people use internal referents to guide them in processing information, while FD people use external referents. F1 people differ in the techniques they use in dealing with complex and confusing events and in reacting to a variety of circumstances in a cognitive way [3]. Relatively FI persons tend to experience parts of the field as discrete from surrounding field, even when the field is so organized as to strongly embed the part; that is, they perceive analytically. Perception of relatively FD persons, on the other hand, is guided by the organization of the field as a whole, so that any part of the field is experiences as continuous with its surround; that is their perception is global. In solving problem, FD person take a long time to find the solution to the class of problem and that class of problem only where solution requires that a critical element be taken out of the context in which it is presented and the problem material restructured with the element used in different context. Relatively FI persons solve such problem more rapidly. FD persons, when in school have also been found to prefer academic areas in which the people side of life is paramount for example social science. In contrast, relatively FI persons have been shown to favor school subject which feature the impersonal and abstract for example mathematics and physical science [5]. Result of previous research Sudarman (2016) and Ramlah 2014 which said math learning outcomes with cognitive style FI was better than cognitive style FD [6,7]

For many children and adults alike, mathematics is a subject that elicits strong negative reactions. Boaler (2009) reports that it is the second most disliked subject. Negative feelings about mathematics cause disaffection or a kind of learning paralysis. Enthusiasm and interest are what make us good learners [8]. Brown and Walter (2005) emphasized that problem posing is to overcome math phobia in their book [9]. Problem posing refers to both the generation of new problems and the re-formulation of given problem [10]." There is good reason to believe that problem generation might be critical ingredient in confronting math anxiety because the posing of problem or asking a questions is potentially less threatening than answering them. The reason is in part a logical one. That is, when you ask a questions, the responses 'right' or wrong are inappropriate, although that category is paramount for answering to questions'[11]. Teachers can use problem posing task to gain greater insight into their students' understanding of mathematics [10]. Lavy and Bershadsky (2003) discovered that the use of problem posing activities contributed to the development for individual's mathematical knowledge. Cunningham (2004) stated that when students created new problem, they increased their sense of responsibility as they constructed their own knowledge while critiquing and refining problem with their classmates [12].

Result of previous research Viktor Verbovsky (2014) and Irene (2016) which says problem posing has significantly increased student's mathematical academic achievement $[6,13]$.

Based on above explanation it is necessary to examine and analyze (1) the difference between students' mathematics learning outcomes whose taught using problem posing learning model with direct learning model (2) the difference between students' mathematics learning outcomes who have field independent with field dependent cognitive style (3) interaction between learning model with cognitive style that effect students' mathematics learning outcomes.

\section{METHOD}

\section{Participants}

The subject were students of primary students 5 grade in Deliserdang. The population consisted of 68 grade 5 students of Chandra Kusuma School in 2016/2017 academic year. The sample consisted of 46 students.

Design

This research used a quasi-experimental design.

\section{Instruments}

Field Dependent-Independent. CEFT (Children's embedded figure test), developed by Stephen A. Karp and Norma Konstadt 1971. The test is composed of a series of items which require the subject to find simple figure embedded within a more complex one. The upper end of continuum of score of CEFT indentifies analytic subjects with lower end of the continuum represent global subjects.

Learning Outcomes. Measured by Mathematics test

Data analysis techniques in this study used Two-way ANOVA

\section{RESULT AND DISCUSSIONS}

\section{a. Result}

The sample were divided into two groups (problem posing and direct learning models). Each group was divided into two group according to scores on the CEFT.

The result were obtained from the student's mathematics test who learned by using problem posing learning models and direct learning models. The results of students' mathematic test showed that the average test score treated with problem posing model is higher than the average test score treated with direct learning model. The result presented in table I.

TABLE I. Mathematic Test Score

\begin{tabular}{|c|c|c|c|c|}
\hline Model & $\begin{array}{c}\text { Cognitive } \\
\text { Style }\end{array}$ & Mean & Std.deviation & $\mathrm{N}$ \\
\hline \multirow{3}{*}{$\begin{array}{c}\text { Problem } \\
\text { Posing }\end{array}$} & FI & 24.43 & 4.43 & 7 \\
\cline { 2 - 5 } & FD & 18.38 & 5.48 & 8 \\
\cline { 2 - 5 } & Total & 21.2 & 5.76 & 15 \\
\hline \multirow{2}{*}{$\begin{array}{c}\text { Direct } \\
\text { Learning }\end{array}$} & FI & 19.29 & 5.94 & 7 \\
\cline { 2 - 5 } & FD & 16.14 & 4.71 & 7 \\
\cline { 2 - 5 } & Total & 17.71 & 5.39 & 14 \\
\hline Total & FI & 21.85 & 5.69 & 14 \\
\cline { 2 - 5 } & FD & 17.33 & 5.58 & 15 \\
\cline { 2 - 5 } & Total & 19.52 & 5.77 & 29 \\
\hline
\end{tabular}

From the two group learning models, it can be seen that the average of problem posing learning outcomes is 21.2 and the average of direct learning is 17.71. The average score of FI student's is 21.85 and the average score of FD student's 
is 17.33. The average of FI learning outcomes is higher than the average of FD learning outcomes for both of learning model.

To find an interaction between learning models and cognitive style on mathematics learning outcomes is used Two-way ANOVA. The result presented in table II

TABLE II. The Result of Analysis Two-way Anova

\begin{tabular}{|c|c|c|c|c|c|}
\hline Source of Variation & df & SS & MS & Fvalue & Ftable= 0,05 \\
\hline $\begin{array}{c}\text { Learning Models } \\
\text { (A) }\end{array}$ & 1 & 87.98 & 87.98 & 8.48 & 4.24 \\
Cognitive Style (B) & 1 & 148.19 & 148.19 & 14.29 & 4.24 \\
Interaction & 1 & 23.19 & 23.19 & 2.24 & 4.24 \\
Error & 25 & 259.36 & 10.37 & - & - \\
\hline Total & 28 & 931.24 & & & \\
\hline
\end{tabular}

From the analysis Two-way Anova, It can be explained that :

The first hypothesis is testing the effect of learning models for mathematic learning outcomes. Based on analysis of the data shows that Fvalue $>$ F table ; $8.48>4.24$, the null hypothesis is rejected so that it can be interpreted there is a different between students' mathematic learning outcomes whose taught using problem posing learning model with direct learning model.

The second hypothesis in this study was the effect of cognitive style on mathematic learning outcomes. Based on the data analysis shows that Fvalue > Ftable ; $14.29>4.24$, the null hypothesis is rejected so that it can be interpreted there is a different between mathematic learning outcomes who have FI with FD cognitive style.

The third hypothesis in this study was the interaction between learning models and cognitive style on mathematic learning outcomes. Based on the data analysis shows that a Fvalue < Ftable ; $2.24<4.24$, the null hypothesis is accepted so that it can be interpreted there isn't interaction between learning models and cognitive style on mathematics learning outcomes. It can be seen in Fig 1. Fig 1 shows that the learning outcomes of mathematics of FI students taught using problem posing learning model is higher than the learning outcomes of mathematics of FD students taught using problem posing learning model. Fig 1 shows that the learning outcomes of mathematics of FI students taught using direct learning model is higher than the learning outcomes of mathematics of FD students taught using direct learning model
Fig. 1. The Interaction between learning models and cognitive style

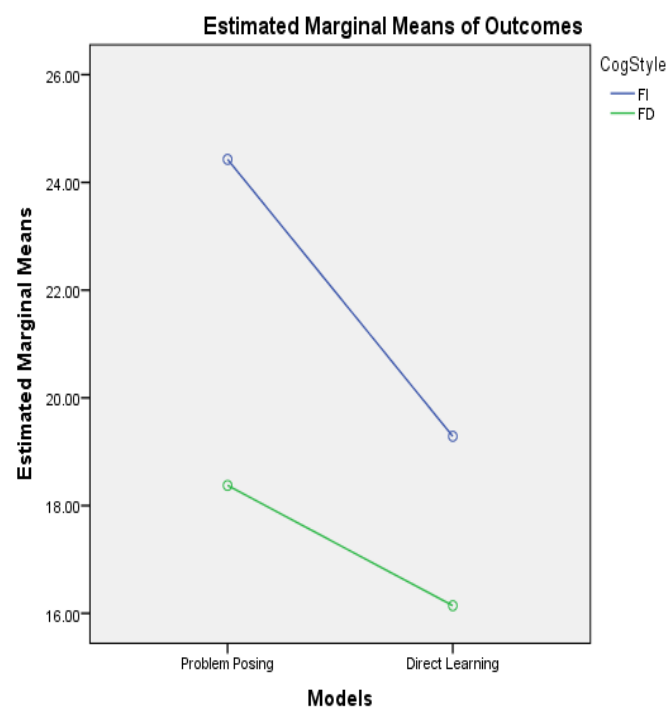

\section{b. Discussion}

The result of the first hypothesis from analysis of two-way Anova showed that the implementation of problem posing learning models was more better than direct learning models. Problem posing learning model has significantly increased student's mathematical learning outcomes. The finding of this study is in line with the finding of previous researchers Viktor Verbovsky (2014) and Irene (2016) which said problem posing has significantly increased student's mathematical academic achievement. In Problem posing, student were not motivated not only finding the correct answer but also the ways that they followed through solution period of the question. Problem posing increase enthusiasm and interest of students. Enthusiasm and interest make them increase mathematical learning outcomes. Problem posing learning models makes students start to like math because problem posing invite students to make their own questions and answer it. It causes the students feel being challenged. Brown and Walter (2005) emphasized that problem posing is to overcome math phobia in their book because the posing of problem or asking a questions is potentially less threatening than answering them.

The result of the second hypothesis from analysis of two-way Anova: there was a different between mathematic learning outcomes who have FI with FD cognitive style. The score of FI students was significantly more better than the score of FD students. The finding of this study was in line with the finding of previous researchers Sudarman (2016) and Ramlah (2014) which said mathematics' learning outcomes with cognitive style FI was better than cognitive style FD. The result showed that the interest of students towards mathematics affects the mathematic achievement. FI students tend to like mathematic lessons. Mathematics has been described as 'the abstract key which turns the lock of the physical universe' (Devlin 2002: 10, citing Polkinhorne). Devlin (2000, 2002) simply describes mathematics as the science of patterns. [8]. 
This was in line with Witkin (1974) which state that FI students prefer to work at math lessons than social science[5]. This statement appropriated with characteristic of FI students can abstract an item from the surrounding field and favor impersonal abstract subjects, such as mathematics tend to be analytical, can solve problems whose materials require structuring [3].

The result of the third hypothesis from analysis of twoway Anova : there wasn't interaction between learning models and cognitive style on mathematics learning outcomes. The group of students who have FI is better in mathematics learning outcomes than the student's group who have FD for both learning models. It shows there wasn't significant interaction between the use of learning model and cognitive style on learning outcomes.

\section{CONCLUSION}

The conclusion of the research are as follows. (1) There is a difference between students' mathematics learning outcomes which is taught using problem posing learning model with direct learning model. The learning outcomes of mathematics taught using problem posing model is higher than the learning outcomes of mathematics taught using direct learning model, (2) There is a difference between student's mathematics learning outcomes who have field independent (FI) and field dependent (FD) cognitive style. The learning outcomes of mathematics of field independent is higher than field dependent students, (3) There is no significant interaction between the use of learning model and the cognitive style on learning outcomes. From the data analysis, it can be concluded that the usage of problem posing learning model is more effective for students who have field independent cognitive style.

\section{REFERENCES}

[1] Arends, L. Richard. "Learning To Teach,” New York : McGraw-Hill 2009.

[2] Cross, Patricia. K. “Accent on Learning," California : Jossey-Bass, Inc. 1979.

[3] Saracho, Olivia. "Teachers' and Students' Cognitive Styles in Early Childhood Education," United States of America : Greenwood Publishing Group, Inc. 1997

[4] Cao, Yu. "Effect of field dependent-independent cognitive style and cueing strategies on students' recall and comphrehension," unpublished.

[5] Witkin, H.A., and Moore, C.A. "Cognitve Style and the Teaching Learning Process," Princeton New Jersey: Educational Testing Service. 1974.

[6] Sudarman, Setyosari Punaji, Kuswandi D, and Dwiyogo D Wasis. "The Effect of Learning Strategy and Cognitive Style Toward Mathematical Problem Solving Outcomes," IOSR Journal of Research \& Method in Education (IOSR-JRME), Vol.6, pp137-143, 2016.

[7] Ramlah. " Relathionship between Students' Cognitive Style (Field Dependent and Field-Independent Cognitive Style) With their Mathematics Achievement in Primary School," International Journal of Humanities Social Sciences and Education (IJHSSE), Vol 1, pp88-93, 2014.

[8] Pound, Linda and Lee Trisha. " Teaching Mathematics Creatively," New York : Routledge. 2011

[9] Singer, M.Florence, Ellerto, F.Nerida and Cai, Jinfa. "Mathematical Problem Posing. New York : Springer. 2015
[10] Silver, Edward. A. "On Mathematical Problem Posing," Canada : FLM Publishing Association. 1994.

[11] Arikan, E.E. and Unal, H.” An Investigation of Eighth Grade Student's Problem Posing Skills (Turkey Sample)," International Journal of Research in Education and Science (IJRES), vol 1, 2015.

[12] Rosli, Roslinda dan Capraro, Mary.M. "The Effect of Problem Posing on Student Mathematical Learning : A Meta-Analysis. International Education Studies, vol. 7, No. 13, pp 227-241. 2014.

[13] Guvercin, Selim. and Verbovskiy, Viktor. "The Effect of Problem Posing Task Used in Mathematics Instruction to Mathematics Academic Achievement and Attitudes toward Mathematics," International Online Journal of Primary Education (IOJPE), Vol. 3, p59-65. 2014. 